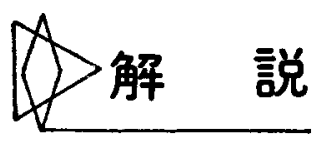

\title{
電子材料における陽極反応膜の応用 ${ }^{*}$
}

1 はじめに

半導体集積回路や薄膜または厚膜回路装置等の電子デ バイスは, 通常, 導電部上なる物質とその導電部を絶縁 保護し，あるいはその導電部を機械的に支持する絶縁物 質とで構成されている.このような “電子材料”として の絶縁材料のうち，特に配線間の絶縁用”とか素子の表 面安定化用 ${ }^{23}$ として酸化物 ${ }^{32}$ の占める割合は大きい，現 在この酸化物の形成方法としては, 酸化性ふん囲気中で 金属や半導体を加熱し酸化被膜を形成する 熱酸化法, あるいは化学的な反応を用いて気相成長させる CVD (Chemical Vapor Deposition) 法等が扔もに使用され ており, 必要に応じてスパッタ法, 蒸着法, あるい注陽 極酸化法等の手段が用いられている. 硝酸等の化学薬品 を用い表面処理をして酸化被膜を形成する方法は, 半導 体装置の分野では, 電気的に信頼度の高い膜が得られな いので普通注使用されていない。

この上うな種々の酸化物形成方法のうち, 特に陽極酸 化法》は（i）高温にすることなく室温に近い温度で酸化 物を形成できる上, (ii) 電流の流れる部分だけ選択的に 酸化物を形成でき, しかも（iii）比較的量産化が簡単で ある等の特徴を持っている，そのため高温にすると金属 間の反応が起きてしまうょうな構造のものに低温で酸化 被膜を形成する必要がある場合等には, この陽極酸化法 が適している.また単に酸化物の形成を目的とするのみ でなく，陽極での電気化学反忘による生成物を利用する 場合もある。

ここでは陽極として用いる材料の種類に応じて,金属,

* 本稿㤬第 14 回腐食防食セミナーでの講演内容を補充し, ま とめたものである。

** 日本電気株式会社集積回路事業部(川崎市中原区下沼部 1753)
絶縁物，半導体の陽極反応を順に記述する．まず金属材 料の陽極酸化の例としては, タンタル薄膜コンデンサの 誘電体材料として用いられている $\mathrm{Ta}_{2} \mathrm{O}_{5}$ 膜の形成およ び半導体集積回路のチップ上のアルミニウム配線の絶縁: 材料として一部使用されている $\mathrm{Al}_{2} \mathrm{O}_{3}$ 膜についてまとめ る. 次いで絶縁材料の陽極酸化の例としてシリコンウエ 一八上の $\mathrm{Si}_{3} \mathrm{~N}_{4}$ 膜を選択的に $\mathrm{SiO}_{2}$ に変換しフッ化水素 酸水溶液で加工できるようにする工程を紹介する．最後 に半導体材料の陽極酸化の例已して, 酸化膜形成以外の 目的で陽極反応を行なわせる例の紹介をかね，シリコン ウエーハをフッ酸水溶液中で陽極反応させて得られる多. 孔質シリコンの利用について言及する.

\section{2 金属材料の陽極酸化}

\section{$2.1 \mathrm{Ta}$}

図 1 は典型的な $\mathrm{Ta}$ 薄膜コンデンサの断面図 ${ }^{5)}$ であ る. 現在陽極酸化法で “量産”されている代表的な電子 材料として, Ta 薄膜コンデンサの誘電体材料である $\mathrm{Ta}_{2} \mathrm{O}_{5}$ をあげることができよう． $\mathrm{Ta}_{2} \mathrm{O}_{5}$ の電気的特性 は, Taの結晶学的構造, Ta中の不純物の種類と量, 電. 解液の種類, さらに陽極酸化膜に取り付ける電極材料の,

Au

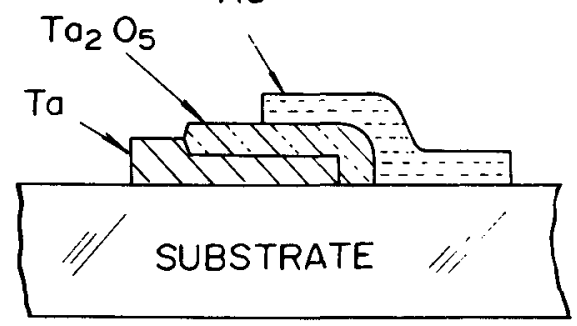

図 1 典型的なタンタル薄膜コンデンサの断面図 ${ }^{52}$ 
金属の種類等に依存する。

表 1 はスパッタ法で結晶学的構造の異なる Ta 膜と N 含有量の異なる $\mathrm{Ta}_{2} \mathrm{~N}$ 膜とを形成し，それを $0.01 \% の$

表 1 基板の種類とシンチレーション電压との閒倸 ${ }^{6)}$

\begin{tabular}{l|r}
\hline \hline \multicolumn{1}{c|}{$\begin{array}{c}\text { Phase of } \\
\text { Ta }\end{array}$} & $\begin{array}{c}\text { Scintillation } \\
\text { voltage }\end{array}$ \\
\hline$\beta-\mathrm{Ta}$ & $120+0.16 V_{\mathrm{f}}$ \\
bcc-Ta $+10-15$ at\% C & $96+0.16 V_{\mathrm{f}}$ \\
hcp $\mathrm{Ta}_{2} \mathrm{~N}$ & $108+0.04 V_{\mathrm{f}}$ \\
hcp $\mathrm{Ta}_{2} \mathrm{~N}$ (higher $\mathrm{N}_{2}$ level) & $81+0.09 V_{\mathrm{f}}$ \\
\hline \hline
\end{tabular}

クエン酸中で陽極酸化して，5\%の $\mathrm{HNO}_{3}$ 液中で測定 したシンチレーション電圧をまとめたものである゙่. こ のシンチレーション電圧以上で陽極反忍を行なわせると 膜に局部的な破壊が生じ，そこで $\beta-\mathrm{Ta}_{2} \mathrm{O}_{5}$ が形成され るので不均一な酸化膜になることが知られているり。こ こで $V_{\mathrm{f}}$ 注陽極酸化電压であるか゚，表に示すように，一 般に $\beta$ - $\mathrm{Ta}$ を用いて陽極酸化して得た $\mathrm{Ta}_{2} \mathrm{O}_{5}$ 膜が最も 高いシンチレーション耐压を示す。

Ta 膜をスパッタ法で形成するときに放電ガス中の $\mathrm{N}_{2}$ の分圧を制御することにより，N 含有量の異なる $\mathrm{Ta}$ 膜 ができる. 図 2 は $\mathrm{N}_{2}$ 分圧を変えて作製した $\mathrm{Ta}$ 膜を陽 極酸化して形成した $\mathrm{Ta}_{2} \mathrm{O}_{5}$ の容量の変化と $\mathrm{N}_{2}$ 分圧と

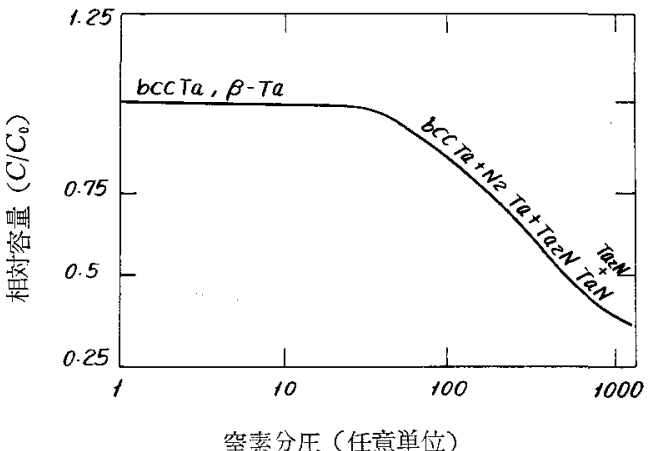

罒 2 スパッタ条件を変えて得た種々の量の空素を含む タンタルを踼極酸化して得た膜の容量と, 窒素分 圧との間係 ${ }^{53}$

の関係を示すものである ${ }^{5}$. N量が少ない試料では $\beta$-Ta または bcc Taを陽極酸化して得た膜の容量と大差はな いが，N量を多くドープすると容量は減少してくる. この方法で小容量のコンデンサを作ることができるが， X線回折法で TaN 構造を示すほどNをドープすると， 陽極酸化膜の容量は急激に減少し，しか子酸化膜の干渉 色も不明りょらになることが知られているのでN量の制 御に注意を要する.

表 2 はスパッタ法で形成した $\mathrm{Ta}$ 膜を種々の電解液中 で陽極酸化したときのシンチレーション電圧を比較した

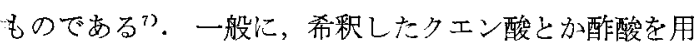

表 2 電解液とシンチレーション電压 ${ }^{7}$

\begin{tabular}{l|c}
\hline \multicolumn{1}{c|}{ Electrolyte } & $\begin{array}{c}\text { Scintillation } \\
\text { voltage }\end{array}$ \\
\hline Conc. $\mathrm{HNO}_{8}$ & 145 \\
$10 \% \mathrm{H}_{2} \mathrm{SO}_{4}$ & 130 \\
$\mathrm{Conc} . \mathrm{H}_{2} \mathrm{SO}_{4}$ & 50 \\
$10 \% \mathrm{H}_{3} \mathrm{PO}_{4}$ & 250 \\
$\mathrm{Conc} . \mathrm{H}_{3} \mathrm{PO}$ & 65 \\
$10 \% \mathrm{NaH}_{2} \mathrm{PO}_{4}$ & $100-140$ \\
$10 \% \mathrm{KNO}_{3}$ & 150 \\
$10 \%$ citric acid & $250-300$ \\
$0.01 \%$ citric acid & $350-400$ \\
$10 \% \mathrm{HAc}$ & 300 \\
\hline \hline
\end{tabular}

いると陽極酸化電圧を高くできる.

表 3 は陽極酸化して得た $\mathrm{Ta}_{2} \mathrm{O}_{5}$ 膜の上に付ける電極 金属の種類を変えたときの絶縁耐圧をまとめたものであ

表 3 電極金属と絶縁耐圧 ${ }^{5}$

\begin{tabular}{l|c|c}
\hline Metal & $\begin{array}{c}\text { Anodic } \\
\text { BDV }\end{array}$ & $\begin{array}{c}\text { Cathodic } \\
\text { BDV }\end{array}$ \\
\hline Au (E) & 91 & $15-20$ \\
Pd (E) & 90 & $15-20$ \\
Cu (E) & 80 & $15-20$ \\
Sb (E) & 75 & $15-20$ \\
Cd (E) & 71 & $15-20$ \\
Fe (E) & 45 & $15-20$ \\
In (E) & 41 & $15-20$ \\
Al (E) & 24 & $15-20$ \\
Ta (S) & 15 & $16-20$ \\
\hline
\end{tabular}

E : Evaporated S: Sputtered

る5). Ta 側を負電位としたときの絶縁耐圧（Cathodic Breakdown Voltage) には電極金属の種類の差異による 影響は現われていないが，Ta 側を正電位としたときの

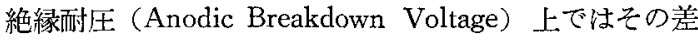
異が顕著に現われており，Au を電極にしたときが最も 高い酎压を示している．通常，密着力の弱、金属ほど陽 極酸化膜の欠陷*1 中への浸透力を持たず， $\mathrm{Ta}_{2} \mathrm{O}_{5}$ の局部 的な欠陌上に“ブリッジ”を作れるのに対し， Al や $\mathrm{Ta}$ のよらに $\mathrm{Ta}_{2} \mathrm{O}_{5}$ に対し密着力の強い金属は $\mathrm{Ta}_{2} \mathrm{O}_{5}$ の欠 陷*1中一浸透して行くので，久陷*1 の耐圧がそのまま現 われる

最近，任藤ら ${ }^{82}$ は $\mathrm{Ta}$ の陽極酸化膜上に高周波スパッ 夕法で $\mathrm{SiO}_{2}$ を付着させ, 低容量領域のコンデンサを作 製した. それによると $0.2 \mu$ 加ら $2.0 \mu の \mathrm{SiO}_{2}$ を形成 することにより $150 \mathrm{pf} / \mathrm{mm}^{2}$ から $20 \mathrm{pf} / \mathrm{mm}^{2}$ のものが得 られている.しかもスパッ夕采件を制御すれば $\mathrm{Ta}_{2} \mathrm{O}_{5}$ の 局部的な欠宿の影響を受けることなく $\mathrm{SiO}_{2}$ を形成でき るので，良品率も $100 \%$ に近いと記述されている。

*1ここでの欠陮はピンホール，または完全に孔が開いていな くても局部的に膜厚が薄くなっている場所のことを指す。 


\section{$2.2 \mathrm{Al}$}

一般に半導体集積回路とか薄膜回路等では Al, Mo, W 等の電極材料をウエー八上または基板上に付着させ, 図 3 の A, Bいずれかの方法で導電配線部を形成している.

A

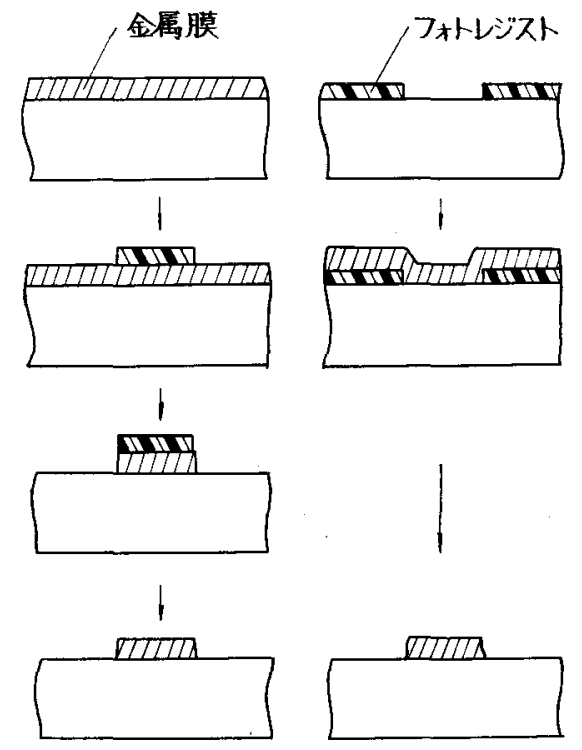

図 3 金属配線形成方法の代表例

すなわちAのように配線材料を付着させた後, 配線とし て残すべきところをフォトレジスト膜で扔扔い, 露出し ている部分を薬品りまたはプラズマ(10)を用いてェッチ ング除去するか, あるいは Bのように, 除去すべき場所 にあらかじめフォトレジストを被せて扮き，その上に電 極材料を付着せしめ，フォトレジストを除去するときに 機械的にフォトレジスト上の電極材料も除去するという 「リフトオフ」11)また注「リフトアウェイ」法22)が用い られている ${ }^{13)}$.しかしこのように配線材料を絶縁膜上に 残寸限り, 図4の上うに, 配線層を重极るとともに表面 の凹凸む著しくなり，上層配線が下層配線を乗り越える ときの断線確率が高くなる.

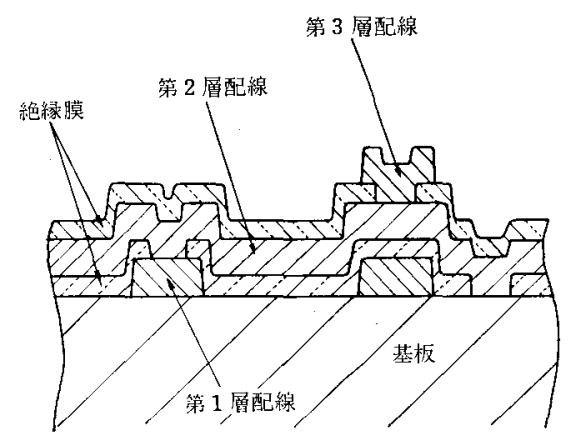

図 4 多層配線構造の断面図の一例
常光ら 14 18) は不要な $\mathrm{Al}$ を選択除去する代わりに, そこを陽極酸化して $\mathrm{Al}_{2} \mathrm{O}_{3}$ に変えてしまら方法を開発 し実用化した。これは図5Aの（a）のように蒸着した

A

(a)

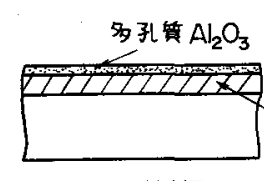

B

(b)

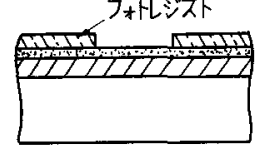

(g)

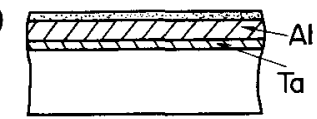

(c)

COMPOSITE $\mathrm{Al}_{2} \mathrm{O}_{3}$

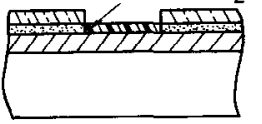

(h)
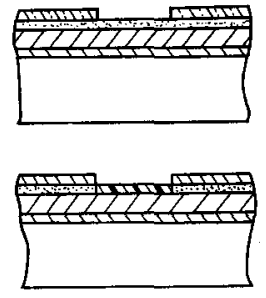

(d)

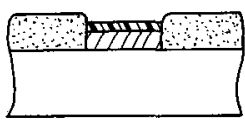

(i)

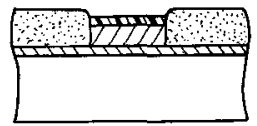

(e)

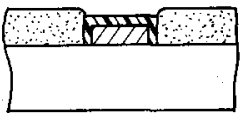

(j)

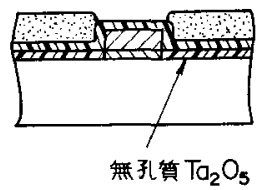

図 5 陽極酸化による配線形成方法

$\mathrm{A}: \mathrm{Al}$ 配線の場合 ${ }^{14)}$ ， B : Al/ Ta 構造の配線の場合 ${ }^{24)}$

$\mathrm{Al}$ の全表面を多孔質 $\mathrm{Al}_{2} \mathrm{O}_{3}$ にし，次いで(b)に示した ようにフォトレジストを付けて，選択的に（c）のように composite $\mathrm{Al}_{2} \mathrm{O}_{3}$ にした後,この composite $\mathrm{Al}_{2} \mathrm{O}_{3}$ をマス

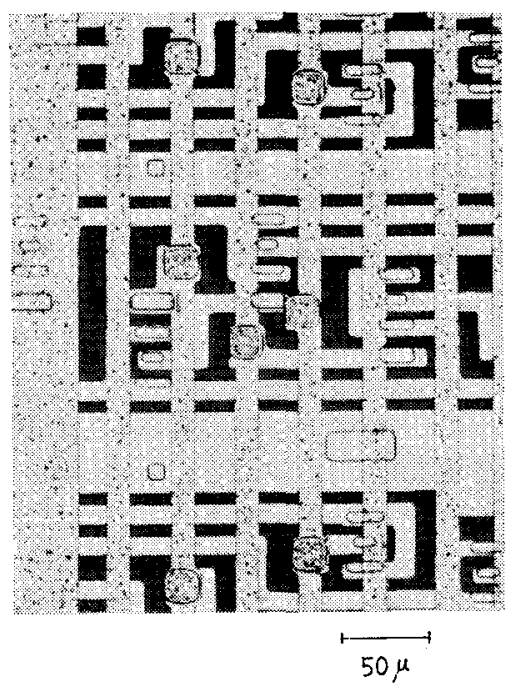

図 6 陽極酸化法によるアルミニウムの二層配線 （常光氏の提供による） 
クにして (d)の上らに配線部以外の $\mathrm{Al}$ を多孔質 $\mathrm{Al}_{2} \mathrm{O}_{3}$ にし，さらに(e)のように配線部の周囲 composite $\mathrm{Al}_{2} \mathrm{O}_{3}$ で被覆するという方法である. 図 6 はこの方法で 作製した集積回路の一例を示す写真である.

上記の方法によると $\mathrm{Al}$ 配線部は陽極酸化膜中に埋込 よれた形になり，チップ面上での配線による段差が著し く減少するため, 多層配線素子の配線工程での良品率が 向上する.さらにまた，この構造では $\mathrm{Si}-\mathrm{SiO}_{2}$ 界面を $\mathrm{Al}_{2} \mathrm{O}_{3}$ で保護することにもなるので, 半導体素子の電気 的特性と信頼性を改善できる ${ }^{142,15), 18)}$. しかも配線部の 周囲を $\mathrm{Al}_{2} \mathrm{O}_{3}$ 膜で押えているので, エレクトロマイグレ ーション*2に対する寿命も伸びる. 図 7 (佐竹ら ${ }^{21), 22)}$ により調べられたこの種の構造のエレクトロマイグレー ションに対する寿命のデータである. Learn ${ }^{23)}$ も同様な 結果を発表している.

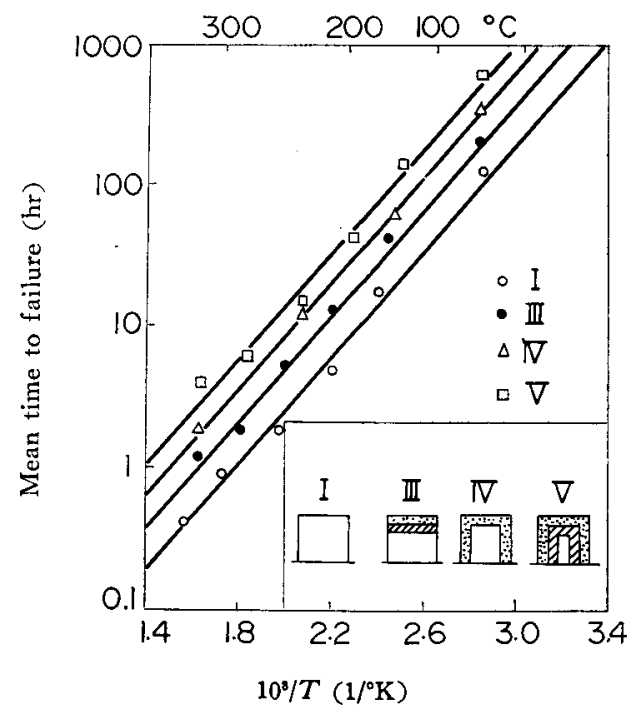

図 7 陽極酸化ナルミナ膜を被覆したアルミニウム配線 のエレクトロマイグレーションに対する寿命 ${ }^{22)}$ $\square:$ フルミニウム，疄圆：多孔質てルミナ， Шִ : Composite フルミナ

$\mathrm{Al}$ 単一の金属を配線材料にする場合だけでなく,「AI/ $\mathrm{Ta}\rfloor ま た は r \mathrm{Al} / \mathrm{Pt} 」$ 構造等のように二種以上の金属を 積み重ねて配線材料とする場合もある.四 $5 \mathrm{~B}$ 亿「Al/ Ta」構造の陽極酸化法む示しておいた ${ }^{24)}$.ここではまず (f)のように希硫酸中で化成し全面に多孔質 $\mathrm{Al}_{2} \mathrm{O}_{3}$ を形 成した後, 選択的に (h) のごとく composite $\mathrm{Al}_{2} \mathrm{O}_{3}$ に し, $\mathrm{A}$ 同様にその composite $\mathrm{Al}_{2} \mathrm{O}_{3}$ をマスクにして(i) のように多孔質 $\mathrm{Al}_{2} \mathrm{O}_{3}$ を形成し，さらにクエン酸中で $\mathrm{Ta}$ 無孔質 $\mathrm{Ta}_{2} \mathrm{O}_{5}$ に変えている.そのとき多孔質 $\mathrm{Al}_{2} \mathrm{O}_{3}$ の下部は（j）のように composite $\mathrm{Al}_{2} \mathrm{O}_{3}$ になる.

*2 通電中に「電子の風」により配線材料の原子が吹き飛ば される現象で，風下には吹き溜りの「丘」が生じ，風上

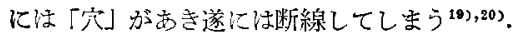

エレクトロマイグレーションを防ぐためCuを，また $\mathrm{Al}-\mathrm{Si}$ 反応を防ぐため $\mathrm{Si}$ をそれぞれ数\%混ぜた合金の Al を配線材料に用いる場合もあるが，一般にこの種の 合金の陽極酸化は困難である. Schwaltz とPlatter ${ }^{25)}$ は 最近この合金の上に純粋な $\mathrm{Al}$ を蒸着し，まずこの $\mathrm{Al}$ で barrier $\mathrm{Al}_{2} \mathrm{O}_{3}$ を作った後で全体を陽極酸化するとよ いと提唱している.

\section{3 絶縁材料の陽極酸化 $-\mathrm{Si}_{3} \mathrm{~N}_{4}$ -}

信頼度の高い $\mathrm{Si}$ 素子を作るには $\mathrm{Si}^{-} \mathrm{SiO}_{2}$ 界面付近が 可動イオンで污染されないようにする必要がある.現在 この可動イオンのおもなものはアルカリイオンであると 言われており ${ }^{26)}, \mathrm{Si}_{3} \mathrm{~N}_{4}$ 膜はこのアルカリイオンに対す

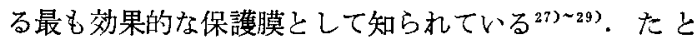
えば Schneer ら ${ }^{30)}$ は $\mathrm{Si}_{3} \mathrm{~N}_{4}$ で $\mathrm{SiO}_{2}$ 上を保護したトラ ンジスタと $\mathrm{SiO}_{2}$ のみのトランジスタををそれぞれ強制 的に $\mathrm{Na}^{+}$イオンで污染しておき，接合温度が $300^{\circ} \mathrm{C}$ に なる条件でフォーミングガス中において電力圾験をした 結果, 後者の電流増幅率は指数関数的に劣化するのに対 し, 前者の試料の電流増幅率は 500 時間まで変らなかっ たと報告している.

上記のような $\mathrm{Si}_{3} \mathrm{~N}_{4}$ 膜の選択エッチング法 ${ }^{30)}$ として は図 $8 \mathrm{~A}$ のように約 $180^{\circ} \mathrm{C}$ の $\mathrm{H}_{3} \mathrm{PO}$ 、を使う場合と図 8 Bに示したように陽極反応を使う方法とがある。すなお

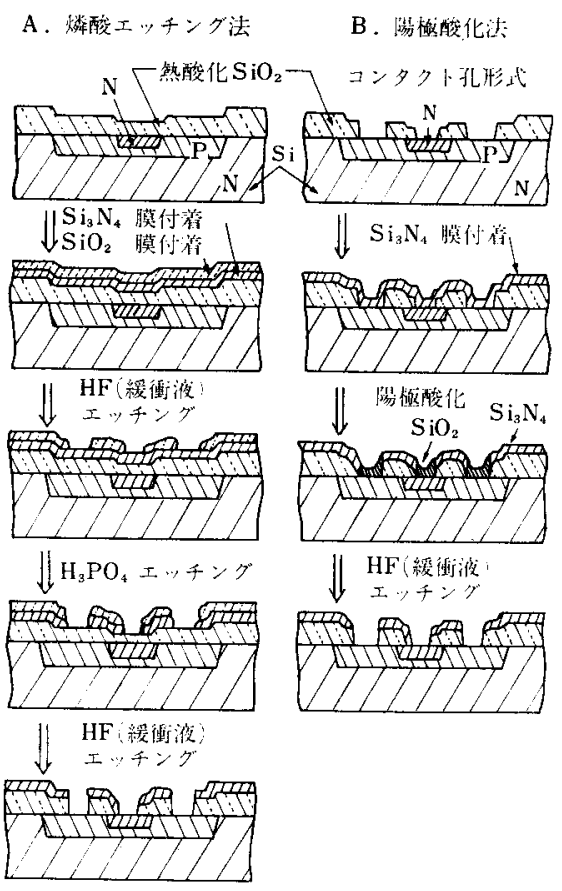

図 $8 \mathrm{Si}_{3} \mathrm{~N}_{4}$ の選択エッチンダ $\mathrm{A}$ : 熱燐酸法, B : 陽極酸化法 
ちAでは $\mathrm{Si}_{3} \mathrm{~N}_{4}$ 上に気相成長法で $\mathrm{SiO}_{2}$ を形成し，その $\mathrm{SiO}_{2}$ を通常のフォトレジスト法で加工し, 次いでこの $\mathrm{SiO}_{2}$ をマスクにして熱 $\mathrm{H}_{3} \mathrm{PO}_{4}$ 中で $\mathrm{Si}_{3} \mathrm{~N}_{4}$ を除去すると いう方法がとられる。それに対しBはあらかじめコンタ
八を陽極酸化し，通電した個所の $\mathrm{Si}_{3} \mathrm{~N}_{4}$ のみ孛 $\mathrm{SiO}_{2}$ に 変え, $\mathrm{HF}$ 水溶液中に浸してその $\mathrm{SiO}_{2}$ 学除去し $\mathrm{Si}_{3} \mathrm{~N}_{4}$ の選択除去を行ならといら方法である。

図 9 は $\mathrm{Si}_{3} \mathrm{~N}_{4}$ の陽極酸化機構索 $2 \mathrm{MeV} の{ }^{4} \mathrm{He}^{+}$イオ ン照射による後方散乱法 ${ }^{31}$ を用いて調べたデータであ

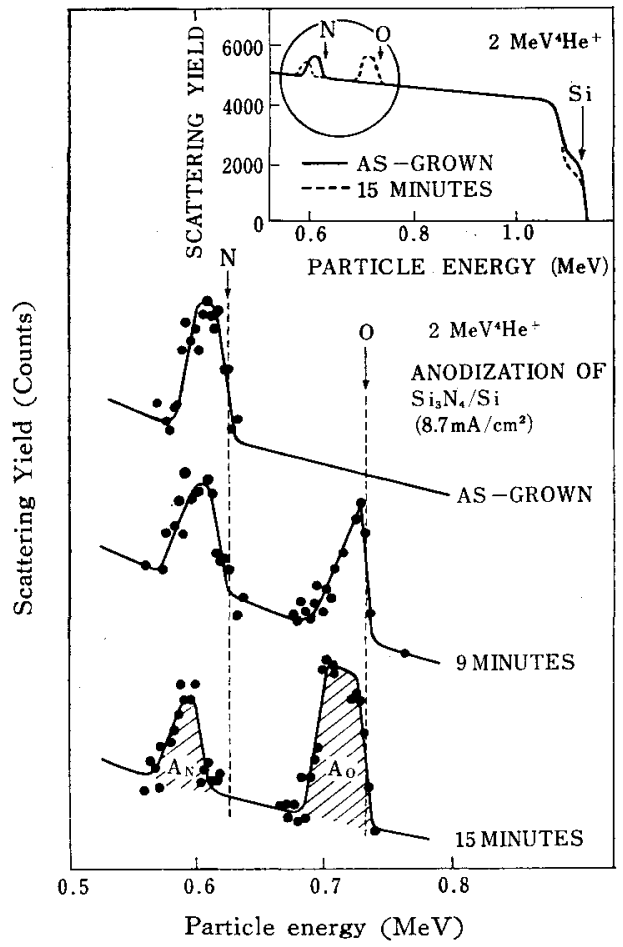

図 $9 \mathrm{Si}$ 上の $\mathrm{Si}_{3} \mathrm{~N}_{4}$ の陽性酸化の様子を示す $2 \mathrm{MeV}$ ${ }^{4} \mathrm{He}^{+}$後方散乱スペクトル

$ろ^{323.33)}$. この場合は $0.97 \mathrm{wt} . \% の \mathrm{KNO}_{3}$ と $1.9 \mathrm{wt} . \%$ の $\mathrm{H}_{2} \mathrm{O}$ と混ぜた $N$ メチルアセトアミドを電解液とし， $480 \AA の \mathrm{Si}_{3} \mathrm{~N}_{4}$ 膜を付けた $\mathrm{Si}$ ウエー八を $8.7 \mathrm{~mA} / \mathrm{cm}^{2}$ の電流で陽極酸化している. 図から明らかなように，時 間とともに $\mathrm{SiO}_{2}$ の $\mathrm{O}$ のスペクトル成分が大きくなる 反面， $\mathrm{Si}_{3} \mathrm{~N}_{4}$ の $\mathrm{N}$ のスペクトル成分が小さくなり，か つ低エネルギー側に移行した。ここは $\mathrm{Si}_{3} \mathrm{~N}_{4}$ の表面側か ら $\mathrm{SiO}_{2}$ が形成されて行くことを意味する.

定電流といら条件に留意し，図9の○のスペクトル成 分とNのスペクトル成分とを解析すると, Nの減少量と Oの増加量とはそれぞれ陽極酸化時間に対し直線関係に あることがわかった.一方, 先に Schmidt とWonsidler ${ }^{34)}$ および Tripp ${ }^{35)}$ はエッチング速度の差と赤外吸収曲線 の観察により, $\mathrm{Si}_{3} \mathrm{~N}_{4}$ の陽極酸化反念を

$$
6 \mathrm{O}^{2-}+\mathrm{Si}_{3} \mathrm{~N}_{4} \rightarrow 3 \mathrm{SiO}_{2}+2 \mathrm{~N}_{2}+12 e^{-}
$$
の式で説明している. 図 9 のイオンビーム後方散乱法で 求めた $\mathrm{O}$ 増加分と $\mathrm{N}$ 減少分との比は，使用した後方 散乱测定装置できまる定数と, 上記の化学反匛式できま る定数とを考慮して求めた計算值と一致した ${ }^{32)}$.

\section{4 半尊体材料の陽極反応 - $\mathrm{Si}-$}

Si の陽極酸化法 ${ }^{36)}$ では熱酸化法ほど電気的に安定な $\mathrm{Si}-\mathrm{SiO}_{2}$ 界面を形成できず，また良質の膜も得難いため 半導体素子に実用化されるところまでには至っていな い.しかし陽極酸化機構そのものの研究は古くからなさ れており ${ }^{37)}$ ，また界面準位の検討結果も報告され ${ }^{38)}$ ，最 近も光照射の効果等が論じられている ${ }^{39}$. 半導体中の不 純物分布を精密に測定するため, 陽極酸化してその酸化 膜をエッチングする操作を繰り返す手法等は広く用いら れている。

電解エッチングのため HF 水溶液中で半導体を陽極反 応させる研究も古くからなされている40),41).この種の電 解液中の Si 電極の性質は西沢，川上ら ${ }^{42), 13)}$ により詳 細に調べられて㧍り，特に正孔の㟢与が指摘されていた. また反応の条件によっては Si 側に陽極反応膜の形成さ れることも知られていだ01,41)、43).

渡辺ら ${ }^{44)}$ は $\mathrm{Si}$ t $\mathrm{HF}$ 水溶液中で陽極反応させて多 孔翼 Si 形成し，その多孔質 Si 熱酸化して，絶稼 物分離形の集積回路素子を作る技術を報告している. 図 10はその一例を示するので, $p$ 型 $\mathrm{Si}$ 基板上に $n$ 型 $\mathrm{Si}$
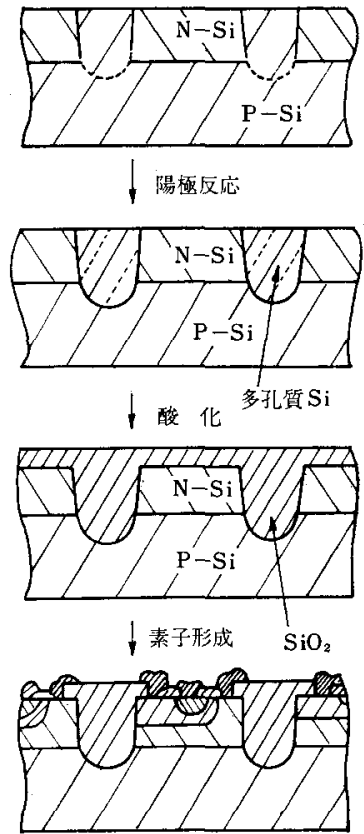

図 10 IPOS 法の一例を示す断面図 ${ }^{46}$ 


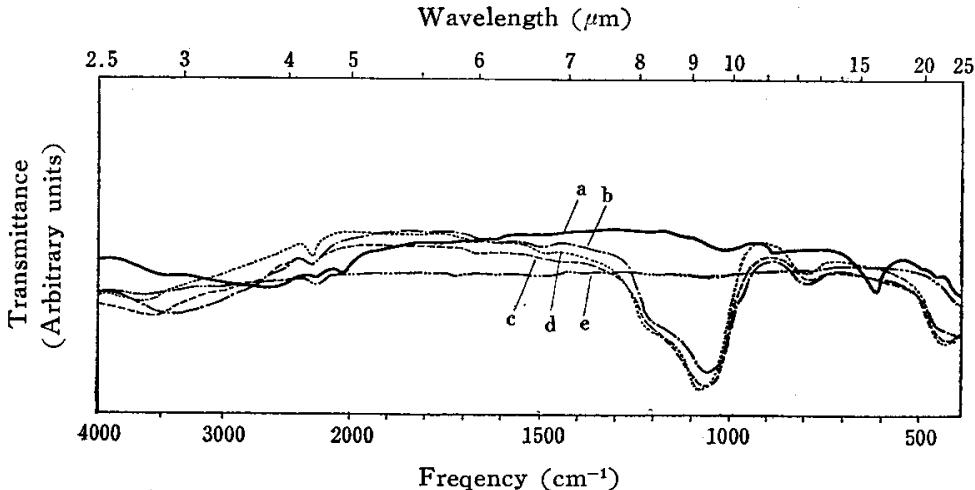

图 $11 \mathrm{Ar}$ 中で $1000^{\circ} \mathrm{C}$ の熱処理を施した多孔質 $\mathrm{Si}$ 層の赤外吸収 曲線の変化 ${ }^{49}$

$\mathrm{a}$ : 陽極反応直後, $\mathrm{b}:$ 熱処理 5 分後, c : 20 分後,

$\mathrm{d}: 60$ 分後, $\mathrm{e}:$ 末反応 $\mathrm{Si}$ を 60 分間熱处理したもの
では一般に電子材料の分野で言う

“清浄ふん囲気”での酸化反応が困 難である.さらにまた，Taの陽極 酸化膜に対する電解液の種類の効果 を一例として述べたように，膜の性 質に対する電解液の効果す無視でき ない，電解液からの污染を防止し， 残留不純物原子を制御して，良質の 反忘生成物を得る条件の追求も今後 の課題である。

本稿をまとめる纪当り，当社，集積回 路事業部 岡田 隆博士と，九州日本電 気株式会社 中沼 尚博士の常日頃のご 指導汇感謝致します。安薄膜コンデン サに関し種々の資料を提供下さった佐藤 恵彦氏，および陽極酸化 $\mathrm{Al}_{2} \mathrm{O}_{3}$ 江よる集積回路の军真を提供下 さった常光秀男氏汇染謝致します。

\section{文献}

1）たと六は，鸭志田元孝，本誌 42，439 (1974).

2）たとえば，岡部太郎，ibid. 42, 490 (1974).

3）たと六涪，垂井康雄，小野員正，菅野卓雄，“MOS 電界 勃果トランジスダ，第 1 章 (1969)，日刊工業新聞社; 德 山巍, “MOS デベイス”，第 2 章，第4 章 (1973), 工業 調查会.

4）たと兄洁，福島敏郎洼か，“陽極酸化”，(1969)，金属表面 技術協会編，朝倉書店；L. Young, “Anodic Oxide Films”, (1961), Academic Pr., London.

5) R.W. Berry, P.M. Hall, M.T. Harris, “Thin Film Technology", pp. 380-387 (1968), D. Van Nostrand Co. Inc.

6) W.D. Westwood, N.Waterhouse, P.S. Wilcox, "Tantalum Thin Film", p. 302 (1975), Academic Press.

7) "Handbook of Thin Film Technology", ed. L.I. Maissel, R. Glang, p. 19-18 (1970), McGraw Hill.

8) S. Sato, A. Sato, E. Okamoto, IEEE Trans. PHP9, 161 (1973).

9）たとえば，梄岡清威，本誌 41，460 (1973).

10）たとえば，阿部東彦，西岡久作，応用物理 44, 881 (1975); 難波 進, 川辺光央, 電通学会誌 59, 117 (1976).

11）三村義昭, 半導体集積回路技術 第 5 回シンポジウム要旨 集, p. 53 (1973).

12）中村喜顕，本城真佐雄，小島快友，塩入信生，半導体集 積回路の生産技術 第 3 回シンポジウム要旨集, p. 29 (1972).

13） 中村 正, 稲垣雄史, 柳田健三, 電通学会誌 59, 106 (1976).

14) H. Tsunemitsu, H. Shiba, Intern. Electron Devices Meeting Abs., p. 128 (1969), Washington, D.C.

15）常光秀男, 柴 宏, 中村明智, 堀切晴喜, 電子通信学会 半導体トランジスタ研究会資料 SSD, 70-49 (1970).

16) H. Tsunemitsu, H. Shiba, NEC Res. \&Dev. No. 25 , p. 74 (1972).

17) H. Tsunemitsu, H. Shiba, This Journal 40, 493 (1972).

18) O. Kuragami, M. Tameda, I. Sasaki, H. Shiba, K. Shimizu, Intern. Electron Devices Meeting Abs., p. 48 (1970).

的ひずみを避けねばならぬ工程に陽極反応はよく利用さ れている。しかし熱酸化法と異なって，この陽極反虑法 
19）たとえば,岡田 隆, 第 10 回半導体尃門講習会予稿集, p. 117-153 (1972); 半導体研究 10, p. 110-135 (1974), 半 導体研究振興会.

20) 岡田隆, 物性 14, 402 (1973).

21) T. Satake, K. Sawaguchi, S.Fujimoto, Electrochem. Soc. Spring Meeting Extended Abs., p. 165 (1971).

22) T. Satake, K. Yokoyama, S. Shirakawa, K. Sawaguchi, Japan J. Appl. Phys. 12, 518 (1973).

23) A.J. Learn, ibid. 44, 1251 (1973).

24) H. Tsunemitsu, 147 th-Electrochem. Soc. Meeting Extended Abs., 75-1, Abs. No. 79 (1975).

25) G.C.Schwartz, V. Platter, J. Electrochem. Soc. 122, 1508 (1975).

26) たとえば, E. Yon, W.H. Ko, A.B. Kuper, IEEE Trans. ED-13, 276 (1966).

27）たとえ活, J.V. Dalton, Recent News at Electrochem. Soc. Meeting (1966).

28) 鴨志田元孝, 電通学会論文誌 (C) 53-C, 214 (1970).

29）鴨志田元孝, ibid. 54-C, 266 (1971).

30) G.H. Schneer, W.V. Gelder, V.E. Hauser, P.F. Schmidt, IEEE Trans. ED-15, 290 (1968).

31）たと光ば, J.W. Mayer, L. Eriksson, J.A. Davies, "Ion Implantation in Semiconductors", Ch. 4, (1970), Academic Press, New York.; 平木昭夫, “半導体研 究”, 11 巻, 第 11 章, p. 265 (1975), 半導体研究振興会 編, 工業調査会刊.

32) M. Kamoshida, J.W. Mayer, Electrochem. Soc. 119, 1084 (1967).

33）鴨志田元孝, 物性 13, 215 (1972).
34) P.F. Schmidt, D.R. Wonsidler, J. Electrochem. Soc. 114, 603 (1967).

35) T.B. Tripp, ibid. 117, 157 (1970).

36) P.F. Schmidt, W. Michel, ibid. 104, 230 (1957).

37）たとえば E.F. Duffek, E.A. Benjamini, C. Mylroie, Electrochem. Technol. 3, 75 (1965).

38) A.G. Revesz, J. Electrochem. Soc, 114, 629 (1967).

39）たとえぼ, 森田孝夫, 南条浡二, 野村 滋, 原 進一, 電子通信学会半導体トランジスタ研究会, SSD75-44 (1975).

40) A. Uhlir, Bell Syst. Tech. J. 35, 333 (1956).

41) D.R. Turner, J. Electrochem. Soc. 105, 402 (1958).

42）川上 明, 西沢潤一, 本誌 34, 280 (1966).

43) 西沢潤一, 川上 明, ibid. 35, 396 (1967).

44）渡辺義雄, 酒井徹志, 通研害用化報告 19, 2101 (1970).

45）有田睦信, 倉成田裕, 春原由雄, 半導体集積回路技術 9 回シンポジウム要旨集, p. 18 (1975).

46) Y. Watanabe, Y. Arita, T. Yokoyama Y. Igarashi, J. Electrochem. Soc. 122, 1351 (1975).

47）たとえば,S. Nakajima, Y. Watanabe, T. Yokoyama, K. Kato, J. Japan Soc. Appl. Phys. Suppl. 44, 303 (1975); 渡辺義雄, 有田睦信, 横山昭男, 応用物理 43, 1046 (1974).

48) B. Cook, Electronics 48 No. 23, p.109 (1975).

49) H. Yamanaka, M. Sakamoto, K. Hamano, Japan J. Appl. Phys. 14, 303 (1975).

50) たとえば, 坂本 充, 鴨志田元孝, 応用物理 44, 497(1975).

51) H. Yamanaka, M. Kamoshida, Y. Haneta, Japan J. Appl. Phys. 13, 1661 (1974). 